\title{
Tarinallisuus taipuu tiedetekstiinkin
}

\author{
Mikko T. Virtanen, Pirjo Hiidenmaa \& Jyrki Nummi (toim.) \\ (2020). Kertomuksen keinoin. Tarinallisuus mediassa ja \\ tietokirjallisuudessa. Gaudeamus. 362 sivua.
}

KERTOMUKSET OVAT kiehtova monitieteinen ja ajankohtainen, moneen näkökulmaan avautuva tutkimuskohde. Niitä tutkitaan niin sosiologian, journalismin kuin kielen ja kirjallisuudentutkimuksen puolella.

Ennen kuin ihmiset osasivat kirjoittaa, he kertoivat asiansa suusta suuhun. Nyt tarinat elävät uutta tulemistaan: ne ovat kiinnostavia ja ne on helppo muistaa. Näin tarinat siirtävät tietoa ja herättävät kiinnostusta.

Tarinan voimaa hyödynnetään kaunokirjallisuudessa, mediateksteissä, mainonnassa ja jopa tietokirjallisuudessa. Esimerkistä käyvät narratiiviset tietokirjat, joissa kokonaisuuden läpi kulkee selkeä juoni. Tarinaa hyödynnetään kertovan ja ei-kertovan tekstin vuorotteluna, tai sillä voidaan havainnollistaa historiallista tarkastelua.

Pirjo Hiidenmaa kysyy, millaista kuvaa tarinallisuudesta rakennetaan luovaa tietokirjallisuutta käsittelevissä oppaissa. Tieteellisen tekstin luova ja kertomuksellinen ote on innostava ajatus, mielletäänhän tiedeteksti herkästi puisevaksi ja vaikeaselkoiseksi. Kirjan lukuisat esimerkit auttavat hahmottamaan asiayhteyden ja tehostavat viestiä.

Kirja itsekin saa voimaa kertomuksista. Ne elävöittävät tekstiä ja tekevät kattavasti lukupaketista varsin helppolukuisen ja kiinnos- tavan. Toisella lukukerralla onnistuin vielä syventämään omia ajatuksiani ja pohtimaan kertomuksen hyödyntämistä laajemmin omissakin teksteissäni. Parhaimmillaan helppolukuisuus myös laventaa tiedekirjan lukijakuntaa.

\section{ANALYSOINNISSA \\ HUOMIOITAVA TEKSTIN LAJI}

Tarinoiden moninainen käyttö asettaa omat haasteensa niiden analysoinnille. Kertomuksia tulee tarkastella suhteessa tekstilajiin sekä yhteiskunnallisiin ja kulttuurisiin yhteyksiinsä. Henkilökohtaiseen kertomukseen saattaa liittyä elämäkerrallinen näkökulma. Kaikki tarinat eivät täytä samoja kriteerejä, eikä niitä voi tarkastella samoista lähtökohdista.

Aiemmin tarinoita tutkittiin lähinnä rakennetyyppien ja retoristen keinojen kautta, sittemmin näkökulma on laajentunut kontekstuaaliseen tarkasteluun ja kerrontaratkaisuihin. Kirjassa 'kertomus' toimii löyhänä kattokäsitteenä, mikä mahdollistaa aiheen tarkastelun monipuolisesti useista näkökulmista.

Esimerkiksi lähteiden ja vaikutteiden merkintä poikkeaa tieto- ja kaunokirjallisuudessa. Kirjassa tuodaan kaunokirjallisuudesta esille kiinnostavia tapauksia, joissa pohditaan alkuperäisen tarinan omis-

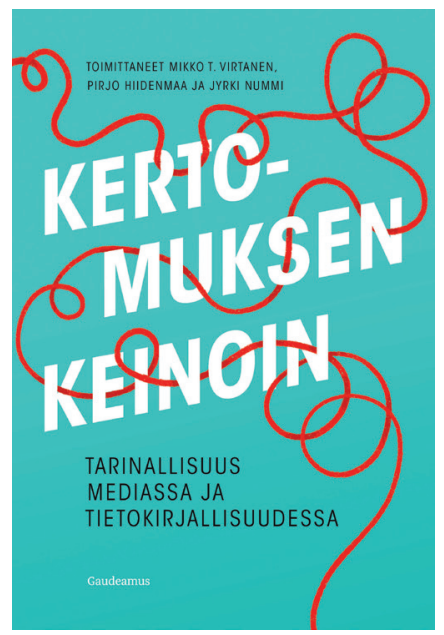

tajaoikeuksia, sitaatti- ja tekijänoikeuksia sekä sitä, kuinka paljon julkaistua tarinaa voidaan lainata.

Sanna Nyqvist kirjoittaa tietokirjallisuudesta kaunokirjallisuuden lähteenä. Hän kuvaa tilanteita, joissa kertomusten omistusoikeudesta on käyty kiistaa aina oikeudessa asti. Tietokirjailija on saattanut tutkia vuosikausia aihetta, jota kaunokirjailija on sitten aina henkilöhahmoja ja jopa sitaatteja myöten hyödyntänyt omassa teoksessaan. Kaunokirjallisuudessa lähteiden merkintää ei edellytetä, joten tiedon alkuperä ja todenperäisyys jäävät arvailujen varaan. Kaunokirjallisuudessakin tosin lähdeluettelot ovat yleistyneet, vaikka niillä ei yhteistä muotoa olekaan. Mutta kuinka pitkälle lainauksissa saa mennä?

\section{KOKEMUKSELLISUUS}

JA YKSITYISKOHDAT

KIINNOSTAVAT

Kerronnan peruspiirteinä voidaan pitää tapahtumasarjan esittelyä, 


\section{OSALLISUUDEN KOKEMUS VÄLITTYY \\ KERTOMUKSEN HENKILÖKOHTAISUUDEN KAUTTA.}

ajallista jäsentymistä, kokemuksellisuuden korostamista ja kiinnostavien yksityiskohtien viljelyä. Näistä elementeistä syntyy innoittava tarina. Kertomus käsittelee yleensä ainutkertaista tapahtumasarjaa ja on tuotettu jonkin tilanteen vuorovaikutustarpeisiin. Asiayhteys on tärkeä: hyväkään tarina ei toimi aina kaikissa tilanteissa.

Faktakirjallisuudessa oletetaan usein automaattisesti kertomusten olevan todellisia. Kaikissa tapauksissa todenperäisyyttä ei ole mahdollista selvittää. Kirjoittajan eettisiä valintoja on sekin, missä valossa ja kenen näkökulmasta asia kertomuksessa tuodaan esille tai millaisia kertomuksia julkisuuteen ylipäätään päätyy.

Siitä on esimerkiksi monia näkemyksiä, voiko opinnäytetyön kirjoittaa minämuodossa. Osallisuuden kokemus välittyy kertomuksen henkilökohtaisuuden kautta, joten kertojaääni voi olla kokonaisuuden kannalta merkittävä.

Kokemuksellisuus ja henkilökohtaisuus saattavat nostattaa keskusteluja siitä, onko tarina todella tapahtunut. Tai puhutaanko vain yhden ihmisen kokemuksesta vai onko ilmiötä yleistettävissä? Pohdintaa voisi jatkaa totuusvaateen merkityksestä:
Voiko kuvitteellinen symbolinen tarina toimia osana faktapitoista tekstiä? Onko lupa havainnollistaa fiktion keinoin?

\section{TIETOKIRJAN OLEMUKSESTA JOURNALISTISEEN KERRONTAAN}

Kirjassa on neljä lukua, joista ensimmäisessä Pirjo Hiidenmaa ja Sanna Nyqvist käsittelevät tietokirjaa kertovan kirjallisuuden kentällä. He pohtivat tieto- ja kaunokirjallisuuden yhteyttä sekä tietokirjojen hyödyntämistä kaunokirjallisuuden lähteenä ja sitä koskevia haasteita.

Toisessa luvussa käsitellään tiedettä yleistajuistavaa tietokirjallisuutta Mikko T. Virtasen, Henri Satokankaan ja Elina Vitikan voimin. Kirjoittajat pohtivat muun muassa tietokirjallisuuden kerrontakäytänteitä ja kertomustyyppejä sekä tekijän identiteettiä ja kertomusten tekstuaalisen persoonan rakentumista.

Kolmannessa luvussa näkökulma laajenee Ilona Lindhin, Anna Hollstenin, Jyrki Nummen ja Päivi Koiviston voimin muuhun tietokirjallisuuteen, kuten matka- ja surukertomuksiin, historiankirjoituksiin ja omaelämäkertoihin.

Neljäs luku on omistettu journalistiselle tarinankerronnalle. Maria Mäkelä ja Laura Karttunen sekä Ralf Kauranen ja Olli Löytty kirjoittavat mallitarinoista sekä kokemuksellisista tarinoista ja sarjakuvasta tarinamuotona.

Kertomuksen keinoin on laaja ja kattava teos. Toimitettuna, usean kirjoittajan voimin tuotettuna se on moniääninen ja sisällöltään laaja. Kirja sopii kaikille, jotka ovat tekemisessä tekstien kanssa. Se antaa ajattelemisen aihetta omien kirjoitusten kehittämiseen ja muistuttaa, että kokonaisuudessa yksittäisilläkin sanavalinnoilla on merkitystä.

HELI ANTILA

YTM, KM, EO,

kirjoittaja ja valmentaja 